\title{
PENINGKATAN PEMAHAMAN KONSEP SISTEM PEMERINTAHAN KABUPATEN, KOTA, DAN PROPINSI DENGAN SMaRT LEARNING
}

\author{
Supartiyani \\ SDN Punung II, Pacitan \\ Email: supartiyani19600113@gmail.com
}

\begin{abstract}
Abstrak: Berdasarkan hasil angket sebelumnya sebagian besar siswa akan belajar jika diberi tugas oleh guru, hanya $10 \%$ siswa yang mendapatkan nilai antara rentangan 70-75.Rendahnya hasil belajar Pendidikan Kewarganegaraan khususnya pada standar kompetensi Memahami Sistem pemerintahan kabupaten, kota, dan propinsi, pada siswa ini merupakan masalah yang serius untuk itu penulis menerapkan SMaRT Learning. Penelitian ini merupakan penelitian tindakan kelas, yang dilaksanakan dalam 4 siklus. Hasil akhir dari penelitian ini menunjukkan bahwa SMART Learning dapat meningkatkan hasil belajar Pendidikan Kewarganegaraan (Memahami Sistem pemerintahan kabupaten, kota, dan propinsi) siswa Kelas IV SD Negeri Punung II Kecamatan Punung Pacitan.
\end{abstract}

Kata Kunci: pemahaman, sistem pemerintahan, smart learning

Pengajaran yang berpusat pada siswa adalah proses pembelajaran berdasarkan kebutuhan dan minat siswa. Strategi pembelajaran yang berpusat pada siswa dirancang untuk menyediakan sistem belajar yang fleksibel sesuai dengan kehidupan dan gaya belajar siswa agar pembelajaran berlangsung efektif dan siswa mencapai hasil belajar yang optimal

Perlu disadari bahwa keberhasilan siswa dalam belajar dipengaruhi oleh banyak faktor, satu diantara faktornya adalah kemahiran siswa untuk belajar mandiri dan memantau kegiatan belajar mereka sendiri. Hasil belajar akan maksimal jika siswa berupaya untuk memiilih kemauan dan menyerap informasi yang baru, didukung adanya informasi yang bermutu sehingga tercipta aktivitas untuk berkreatifitas, merefleksikan kegiatan belajar dan menyimak ketuntasan yang dicapai, seerta didukung suasana pembelajaran yang kondusif yang memungkinkan siswa dapat belajar sesuai gaya belajar yang dimiliki dan tidak kalah penting tersedianya waktu belajar yang cukup dan tercukupinya sarana dan prasarana belajar.

Berdasarkan hasil angket sebelum penelitian menunjukkan bahwa sebagian besar siswa akan belajar jika diberi tugas oleh guru. Siswa belum mampu mengambil makna dari belajar, kemauan siswa untuk mengembangkan kreatifitasnya masih rendah, kegiatan belajar siswa masih tergantung pada guru.

Hasil ulangan siswa maupun pekerjaan rumah menunjukkan bahwa siswa belum mampu mengembangkan konsep yang dimiliki. Hal ini terbukti bahwa dalam menanggapi informasi yang berkenaan dengan Pendidikan Kewarganegaraan $(\mathrm{PKn})$ masih mengikuti contoh guru secara persis. Jika katakata dalam tugas atau ulangan itu diganti, $90 \%$ siswa tidak dapat mengerjakan. Akibatnya hasil belajar Pendidikan Kewarganegaraan siswa rendah. 
Dari dokumen yang telah dikumpulkan penulis tentang hasil belajar Pendidikan Kewarganegaraan yang diambil dari portofolio dan daftar nilai tentang penguasaan dan penerapan konsep Pendidikan Kewarganegaraan, hanya $10 \%$ siswa yang mendapatkan nilai antara rentangan 70-75. Selain kurang maksimalnya upaya siswa dalam belajar Pendidikan Kewarganegaraan hal ini dikarenakan guru kurang efektif dalam memberikan bimbingan belajar kepada siswa dan belum terciptanya iklim pembelajaran yang menyenangkan yang mampu memberikan kebebasan siswa untuk belajar Pendidikan Kewarganegaraan. Rendahnya hasil belajar Pendidikan Kewarganegaraan khususnya pada standar kompetensi Memahami Sistem pemerintahan kabupaten, kota, dan propinsi, pada siswa ini merupakan masalah yang serius yang harus segera ditangani, sebab jika tidak akan membawa akibat yang fatal, misalnya siswa tidak naik kelas. Untuk itu penulis menawarkan alternatif untuk memecahkan permasalahan terserbut dengan mencoba menerapkan SMaRT Learning, yaitu suatu metode pembelajaran yang pelaksanaannya melewati beberapa pentahapan yaitu : Serap, Maknai, Rayakan, dan Terapkan. Dengan harapan pemahaman konsep yang bermuara pada hasil belajar Pendidikan Kewarganegaraan pada standar Kompetensi : "Memahami system pemerintahan kabupaten,kota,dan provinsi" dan khususnya pada Kompetensi Dasar " Mengenal lembaga-lembaga dalam susunan pemerintahan kabupaten, kota, dan provinsi. untuk aspek penguasaan dan penerapan konsep meningkat yaitu $80 \%$ siswa mampu memperoleh nilai 75 ke atas.

Diperlukan tindakan untuk memecahkan masalah tersebut. Tindakan yang dirasa tepat untuk mengatasi permsalahan tersebut adalah melalui penerapan SMaRT Learning. SMaRT Learning merupakan metode terapan yang menekankan pada prinsip belajar mandiri. Pada penerapan SMaRT Learning siswa diajak belajar secara pintar dengan pentahapan : Serap, Maknai, Rayakan, dan Terapkan. Ditengarai dengan menerapkan metode ini situasi kelas menjadi lebih menyenangkan dan konsentrasi siswapun dapat terpusat dalam pembelajaran.

Pada penerapan SMART Learning siswa diajak belajar secara pintar dengan pentahapan : Serap, Maknai, Rayakan, dan Terapkan ( Thomas L.Madden, 2002 : 143 ). 2. Pemahaman konsep merupakan kata lain dari prestasi belajar adalah Menurut Kamus Bahasa Indonesia disebutkan bahwa " prestasi belajar adalah hasil yang telah dicapai (dari yang telah dilakukan, dikerjakan dan sebagainya). Dengan demikian hasil belajar Pendidikan Kewarganegaraan berarti hasil Pelajaran Pendidikan Kewarganegaraan yang diperoleh dari kegiatan persekolahan yang bersifat kognitif dan biasanya ditentukan melalui pengukuran dan penelitian. (Kamus Besar Bahasa Indonesia : 1989: 700).

SMaRT Learning merupakan metode terapan yang penulis adopsi dari beberapa buku tentang teori belajar dan pembelajaran yang disesuaikan dengan karakteristik penulis sebagai guru dan siswa SDN Punung II. Pada penerapan SMaRT Learning siswa diajak belajar secara aktif dengan pentahapan : Serap, Maknai, Rayakan, dan Terapkan.

Tahap Serap adalah tahap membangkitkan motivasi belajar siswa untuk gemar Pendidikan Kewarganegaraan dengan cara belajar sesuai dengan gaya 
belajar masing-masing siswa, sehingga siswa termotivasi dalam menggali makna serta menghargai perbedaan. Tahap Maknai adalah tahap Maknai dalam menyerap informasi dengan lima gaya belajar yaitu : Auditori, Kinestesis, Visual, Olfaktori, dan gustatory. Dari lima gaya belajar tersebut ada tiga gaya belajar utama yaitu : visual, auditori, dan kinestesis. ( Thomas L.Madden, 2002 : 143 ) Semakin banyak indra yang dilibatkan dalam proses pembelajaran semakin banyak dan semakin kuat informasi yang diserap. Tahap Rayakan adalah keaktifan dalam memaknai materi yang diserap dan dipahami siswa dimana siswa berupaya menghubungkan informasi baru ke dalam pengetahuan dasar yang telah dimiliki saat ini sehingga tercipta konsep.

Maka dari itu dilakukan lah penelitian yaitu, peningkatan pemahaman mata pelajaran pendidikan kewarganegaraan pada standar kompetensi "Pemerintahan kabupaten, kota, dan provinsi" dengan menerapkan model pembelajaran SMaRT Learning. Penelitian ini bertujuan yang akan dicapai pada penelitian ini adalah meningkatkan pemahaman konsep Sistem Pemerintahan kabupaten, kota, dan provinsi Siswa Kelas IV SDN Punung II Semester II Tahun Pelajaran 2015/2016.

\section{METODE PENELITIAN}

Penelitian ini dilakukan di SDN Punung II, SDN Punung II terletak di desa Punung Kecamatan Punung Kabupaten Pacitan Propinsi Jawa Timur. Letak sekolah tempat penelitian ada di pedesaan. Sebagai subyek penelitian tindakan kelas ini adalah siswa Kelas IV pada Semester II tahun pelajaran 2015/2016 Jumlah siswa 15 siswa terdiri atas 7 Laki-laki dan 8 perempuan. Mayoritas siswa berasal dari keluarga menengah kebawah.

Untuk membekali siswa sebagai pembelajar mandiri penulis membagikan materi strategi-strategi belajar dan mengulasnya menggunakan bluebort. Penulis juga memberikan pengetahuan dan contoh penerapan tentang gaya belajar, delapan tipe kecerdasan, pentingnya refleksi dan pentingnya memanfaatkan sumber daya yang tersedia di sekitar untuk meningkatkan hasil belajar.

Agar semua gaya belajar terlayani penulis menyiapkan beberapa media pembelajaran berupa gambar, model dan perangkatnya, juga tape dan musik instrumental (kaset) yang diputar selama pertemuan 1 berlangsung. Penulis juga menyiapkan lembar penilaian, lembar observasi, serta soal-soal ulangan. Semua hasil penilaian ditempel dalam papan informasi kelas. Rencana tindakan dalam penelitian ini terdiri dari 4 tahapan : Tahap perencanan, Tindakan, Observasi dan Refleksi.

Secara terperinci kegiatan masing-masing siklus dipaparkan sebagai berikut : a. Perencanaan; Penelitian tindakan kelas ini dilaksanakan dalam 4 siklus. Suklus I dan 2 terdiri atas 2 kali pertemuan. Pertemuan I melakukan tahap Serap, Maknai, Rayakan, sedangkan pertemuan ke 2 melakukan tahap Terapkan. Siklus 3 dan 4 terdiri dari 1 pertemuan. Tahap Serap, Maknai dan Rayakan dilakukan siswa di rumah, sedangkan tahap Terapkan dilakukan di sekolah.

Materi yang dibahas berkaitan dengan Standar Kompetensi Sistem pemerintahan kabupaten, kota, dan provinsi khususnya pada Kompetensi Dasar “ Mengenal lembaga-lembaga dalam susunan pemerintahan kabupaten, kota, dan 
propinsi" siklus I dan siklus II tentang "lembaga dan susunan pemerintahan kabupaten/kota " pada siklus 3. dan siklus 4 Pemerintahan kabupaten/kota.

Penelitian dilaksanakan dalam 4 siklus. Pada tahap ini meliputi kegiatan :

1) Membuat desain pembelajaran, 2) Menyiapkan media pembelajaran disesuaikan dengan materi yang dibahas, 3) Menyiapkan tape dan kaset Mozart, 4) Menyiapkan lembar penilaian hasil refleksi dan lembar observasi presentasi serta soal ulangan tahap 1 dan 2

Tahap Tindakan : Pada tahap ini berupa kegiatan melaksanakan melalui tahap-tahap berikut : 1) Tahap Serap guru membangkitkan motivasi belajar siswa untuk gemar Pendidikan Kewarganegaraan dengan cara belajar sesuai dengan gaya belajar masing-masing siswa, sehingga siswa termotivasi dalam menggali makna serta menghargai perbedaan dengan memperlihatkan media pembelajaran yang akan digunakan. 2) Tahap Maknai : siswa menyerap informasi untuk dipahami dengan membaca, mengamati gambar dan menyentuh model. 3)Tahap Rayakan: siswa memaknai informasi yang diperolehnya, menghubungkan dengan pengetahuan dasar yang telah dimiliki, mengorganisir materi dengan caranya sendiri sehingga mudah dipahami dan diingat. selama menyerap dan memaknai informasi, siswa dapat memilih kondisi terbaiknya. Setelah itu membuat refleksi tertulis.

Tahap Terapkan : siswa merefleksikan hasil menyerap dan memaknai informasi secara tertulis dalam beraneka bentuk : rangkuman, skema atau tabel. Untuk mengaktifkan otak kanan, hasil refleksi diwarnai atau ditandai. Siswa diberi waktu untuk menyimpan informasi ke dalam otak dan mengingatnya kembali memindahkan memori jangka pendek ke memori jangka panjang). Untuk menentukan tindak lanjut perlu dicek adanya hasil ketuntasan secara mandiri, seorang siswa melakukan presentasi. Siswa mengucap salam, lalu dengan mengepalkan tangan dia mengucap "I am is SMaRT Learning" siswa lain menyemangati dengan menyambut "Okey" sambil mengepalkan tangan pula. Presentasi ditanggapi dengan Tanya jaawab. Setelah presentasi berakhir siswa kembali duduk, guru memberikan umpan balik kepada seluruh kelas dengan bertanya "What is he SMaRT Learning ?" Siswa lain menjawab "yes or No" sesuai dengan keadaan presenter. Selama tahap ini , guru dapat mengevaluasi tingkat ketuntasan dan kebenaran konsep siswa. Selanjutnya guru bertindak sesuai kebutuhan kelas. Setelah tahap ini selesai siswa mengerjakan ulangan tahap I.

Tahap Observasi, Observasi ini dilaksanakan secara rinci atas semua peristiwa yang berkaitan dengan kegiatan penelitian, diantaranya : 1) Pelaksanaan pembelajaran, 2) Akltifitas guru dalam mengelola kelas, 3) Aktifitas siswa saat mengikuti pembelajaran, 4) Respon siswa terhadap pembelajaran, 5) Media yang digunakan dalam pembelajaran, 6) Pelaksanaan penilaian proses. Observasi ini diikuti dengan pencatatan lapangan yang memungkinkan peneliti mendapatkan temuan-temuan, baik temuan utama maupun temuan ikutan. Pada tahap ini penulis mengamati kegiatan siswa menggunakan beberapa instrument yaitu : 1) Lembar penilaian hasil refleksi tertulis tertulis untuk menilai hasil refleksi setelah tahap Serap dan Maknai, lembar tes ulangan tahap 1 untuk menilai hasil belajar setelah tahap Serap, Maknai dan Rayakan. 2) Lembar observasi untuk menilai kemampuan presentasi siswa serta lembar tes ulangan 2 untuk menilai hasil 
belajar setalah tahap Terapkan. 3) Catatan lapangan sebagai data kualitatif untuk mendukung data penelitian yang dilaksakan.

Tahap refleksi, atas dasar hasil observasi dilakukan refleksi yang mencakup : 1) Pengungkapan hasil observasi oleh peneliti, 2) Pengungkapan tindakan- tindakan yang dilakukan siswa, 3) Pengungkapan tindakan-tindakan yang telah dilakukan guru selama mengajar. Hasil pengamatan berupa data kuantitatif maupun kualitatif direfleksikan. Hasil refleksi dipakaikai sebagai dasar untuk menentukan langkah perbaikan pada siklus berikutnya.

Teknik pengumpul data merupakan cara yang digunakan peneliti untuk mencari sesuatu yang diharapkan secara sistematis, dan terencana. Alat Pengumpul data pada penelitian ini menggunakan teknik tes dan non tes. Secara rinci dapat dipaparkan sebagai berikut :

Tes Hasil Belajar, Tes hasil belajar yang dimaksud adalah tes hasil belajar mata pelajaran Pendidikan Kewarganegaraan yang diikuti siswa Kelas IV Dari nilai hasil belajar inilah akan dipakai sebagai petunjuk untuk menentukan kecenderungan ketuntasan belajar siswa atas dasar standart ketuntasan belajar Pendidikan Kewarganegaraan yang telah ditetapkan, serta untuk mengetahui peranan SMaRT Learning dalam upaya meningkatkan hasil belajar Pendidikan Kewarganegaraan. Data yang diperoleh berupa data kuantitatif, yang berupa nilai tes Pendidikan Kewarganegaraan. Sumber data adalah subyek penelitian. Instrumen tes dibuat oleh peneliti.

Angket, Angket merupakan alat pengumpul data yang berisi daftar pertanyaan dan pernyataan secara tertulis yang ditujukan kepada responden atau subyek penelitian yang berguna untuk mengetahui hal yang dintatakan dalam penelitian, Menurut Suharsini Arikunto, 1993:124 : Angket atau questioner adalah sejumlah pertanyaan tertulis yang digunakan untuk memperoleh informasi dari responden dalam arti laporan pribadinya atau hal-hal yang diketahui.

Dokumentasi, Teknik dokumentasi yaitu mengumpulkan data melalui peninggalan tertulis, terutama berupa arsip-arsip termasuk buku tentang teori, dalil, hukum dan lain-lain yang berhubungan dengan masalah penelitian. Dokumen yang dimaksud adalah nilai mata pelajaran Pendidikan Kewarganegaraan pada semester sebelumnya dan hasil ulangan harian pada semester yang sedang berjalan yang telah dicapai siswa. Data dokumen ini dijadikan sumber informasi sebagai dasar penentuan situasi awal penelitian. Menurut kajian penulis bahwa data tersebut benar dan dapat dipertanggungjawabkan dan memenuhi syarat.

Sehubungan dengan teknis analisa data, dalam mengolah data poeneliti menggunakan analisis deskriptif. Deskripsi ubahan hasil belajar Pendidikan Kewarganegaraan dilakukan dengan mentabulasi skor ubahan berupa harga rerata, nilai tertinggi, dan nilai terendah yang dikemudian dianalisis secara prosentase. Adapun standar ketuntasan belajar Pendidikan Kewarganegaraan yang telah ditetapkan $75 \%$.

\section{HASIL PENELITIAN DAN PEMBAHASAN}

Penelitian diawali dengan mengumpulkan informasi dengan menyebar angket. Berdasarkan hasil angket sebelum penelitian menunjukkan bahwa 
sebagian besar siswa akan belajar jika diberi tugas oleh guru. Siswa belum mampu mengambil makna dari belajar, kemauan siswa untuk mengembangkan kreatifitasnya masih rendah, kegiatan belajar siswa masih tergantung pada guru.

Hasil angket didukung dengan dokumen tentang hasil ulangan siswa maupun pekerjaan rumah menunjukkan bahwa siswa belum mampu mengembangkan konsep yang dimiliki. Hal ini terbukti bahwa dalam mengerjakan soal Pendidikan Kewarganegaraan masih mengikuti contoh guru secara persis. Jika kata-kata dalam tugas atau ulangan itu diganti, 90\% siswa tidak dapat mengerjakan. Akibatnya hasil belajar Pendidikan Kewarganegaraan siswa rendah.

Dari dokumen yang telah dikumpulkan penulis tentang hasil belajar Pendidikan Kewarganegaraan yang diambil dari portofolio dan daftar nilai tentang penguasaan dan penerapan konsep Pendidikan Kewarganegaraan, hanya $10 \%$ siswa yang mendapatkan nilai antara rentangan 70-75. Selain kurang maksimalnya upaya siswa dalam belajar Pendidikan Kewarganegaraan hal ini dikarenakan guru kurang efektif dalam memberikan bimbingan belajar kepada siswa dan belum terciptanya iklim pembelajaran yang menyenangkan yang mampu mnemberikan kebebasan siswa untuk belajar Pendidikan Kewarganegaraan.

Penelitian ini dilaksanakan dalam 4 siklus yang secara keseluruhan terdiri atas 6 kali pertemuan. Secara terperinci, seluruh rangkaian pelaksanaan penelitian dengan hasilnya adalah sebagai berikut:

Siklus I, a. Perencanaan: 1) Menyusun Silabus Pembelajaran, dalam menyusun silabus pembelajaran memperhatikan materi dan menyesuaikan dengan Standar Kompetensi dan Kompetensi Dasar yang harus dikuasai siswa. 2).Menyusun Rencana Pelaksanaan Pembelajaran, Rencana Pelaksanaan Pembelajaran yang disusun disesuaikan dengan Silabus Pembelajaran yang telah dikembangkan. Pembahasan materi. Sedangkan strategi pembelajarannya menerapkan pendekatan konstruktivisme.. Hal ini dimaksudkan untuk menarik minat dan kreativitas siswa. 3). Menyiapkan Lembar Kerja Siswa,Lembar Kerja Siswa sengaja dibuat agak mudah tetapi mampu mengaktifkan siswa. 4)Menyiapkan Soal Tes Tulis, Soal Tes Tulis pada siklus I ini terdiri dari 5 soal dengan skor maksimal 100. 5). Menyiapkan Lembar Observasi, Lembar Observasi digunakan untuk mengetahui bagaimana aktivitas siswa selama pembelajaran, aktivitas guru dan kesesuaiannya dengan silabus yang dirancang. Lembar observasi tentang pembelajaran strategi SMaRT Learning Mata Pelajaran Pendidikan Kewarganegaraan untuk guru dan siswa. 6). Membuat angket, untuk mengetahui respon siswa setelah pembelajaran dan respon guru terhadap proses pembelajaran. Angket siswa terdiri dari pertanyaan tentang menyenangkan atau tidak, pemahaman soal. Angket guru meliputi peran dalam SMaRT Learning, keuntungan maupun kerugian penggunaan SMaRT Learning. 7) Menyiapkan fasilitas yang diperlukan dalam pembelajaran, sehari sebelum pelaksanaan penelitian pada siklus I, siswa diberitahu untuk membawa alat-alat tulis lengkap ditambah membawa gunting, lem atau isolasi, serta kertas lipat. Guru juga mempersiapkan untuk antisipasi bagi siswa yang lupa tidak membawa perlengkapan. 8). Menyusun strategi observasi dan pelaksanaan penelitian. Kelas 
IV sebagai kelas penelitian terdiri 15 siswa. Sebagai guru/pengajar ditentukan Gurui kelas IV, sedang lainnya sebagai pengamat/ observer. Kemampuan siswa dalam kelas tersebut termasuk kelas normal, artinya terdapat siswa dari kelompok tinggi, kelompok sedang dan kelompok rendah. Selain itu pembagian kelas di sekolah tidak berdasarkan pada kemampuan siswa, tetapi dari urutan nomor induk siswa. Dalam pengamatan disepakati dilakukan 2 orang guru. Refleksi dilakukan bersama-sama berdasarkan catatan-catanan guru pengamat selama pembelajaran berlangsung.

Pelaksanaan, 1) Pertemuan 1, Tindakan yang telah direncanakan diterapkan pada saat berlangsung kegiatan pembelajaran. Pada tahap Serap guru membangkitkan motivasi belajar siswa dengan memperlihatkan media yang akan digunakan. Kemudian guru membunyikan kaset instrumental dengan suara sayupsayup selama satu bertemuan. Guru memberi penjelasan singkat tentang materi ajar. Siswa diminta mengarahkan perhatiannya pada nara sumber, siswa menyiapkan peralatan yang diperlukan. Selanjutnya guru memberi contoh sederhana, dan mengmaknai kriteria penilaian. Pada tahap Maknai guru menugasi siswa untuk mengamati gambar maupun model. Pada tahap Rayakan siswa dibimbing untuk untuk memaknai informasi yang diperolehnya dengan caranya sendiri. Kemudian siswa diberi tugas. 2) Pertemuan 2, Pada pertemuan 2 pada penelitian ini guru mengadakan tanya jawab tentang materi ajar pada petemuan sebelumnya . Selanjutnya siswa diminta untuk merefleksikan informasi yang telah diserapnya secara tertulis dalam beraneka bentuk. Sebagai upaya mengembangkan kreatifitas siswa, siswa diberi kebebasan untuk memberi tanda atau mewarnai hasil refleksi tertulis.

Untuk menentukan tindak lanjut secara bermusyawarah guru meminta seorang siswa melakukan presentasi. Untuk menyemangatinya kegiatan presentasi disambut dengan tepuk tangan dan memperkenalkan diri, dengan ucapan 'I am is SMaRT Learning" siswa lain menyambut dengan semangat "Okey" Selesai presentasi guru minta pendapat siswa lain " What is he SMsRT Learning?" siswa lain menyambut dengan kata "Yes or No " sesuai dengan kondisi presenter. Guru meminta siswa untuk memajangkan hasil dan yang lain mmasukkannya dalam portofolio. Kegiatan diakhiri dengan ulangan.

Pada tahap Observasi dilaksanakan proses observasi terhadap pelaksanaan tindakan dengan menggunakan lembar observasi yang telah dibuat dan mengadakan penilaian untuk mengetahui kemampuan siswa dalam mendeskripsikan materi ajar. Dari hasil observasi pada siklus I diperoleh data bahwa aktivitas siswa termasuk dalam kategori cukup.

Jika dilihat dari tingkat ketuntasan belajar siswa diketahui bahwa hasil belajar siklus I terendah adalah 45 sedangkan tertinggi 75 Skor rata-rata siswa adalah 62,73. dengan tingkat ketuntasan 18,18\%. Berarti terdapat 2 siswa yang mampu mencapai nilai 75 atau lebih. Jadi kemampuan siswa dalam mendeskripsikan pengertian organisasi tergolong rendah dan belum memenuhi indikator keberhasilan yang ditetapkan yaitu $75 \%$. Oleh karena itu perlu ditingkatkan lagi pada pertemuan berikutnya. 
Hasil pengamatan terhadap guru penerapan model SMaRT Learning menunjukkan hasil cukup memuaskan karena guru telah mengikuti langkahlangkah SMaRT Learning dengan benar.

Pada tahap Serap dan Maknai, 2 siswa tetap berada di ruangan dengan cara belajar : duduk manis, membaca serius dan menyalin informasi. Ada 2 siswa keluar ruangan dan melakukan kegiatan yang sama. Hasil refleksi semuanya tertulis. Hasil penilaian refleksi terlampir.

Selama tahap Serap , Maknai dan Rayakan diperoleh data sebagai berikut: menit 1 sampai menit 20, siswa konsentrasi menyerap, memaknai dan menyimak hasil pemaknaannya. Mulai menit ke 21, ada 7 siswa yang ke luar ruangan dan 8 siswa tetap berada di ruangan dengan tingkah laku beragam. Bentuk refleksi tertutis siswa sebagai berikut : 7 bentuk table, 3 bentuk ringkasan deskriptif yang ditandai, 2 bentuk ringkasan deskriptif tanpa ditandai. Hasil refleksi terlampir.

Pada akhir tahap Terapkan, guru menguatkan pengertian organisasi dan memberi solusi untuk memudahkan memahami dan mengingat perbedaan yang ada pada jenis organisasi yang berbeda. Pada ulangan akhir siklus I siswa yang memperoleh nilai 75 ke atas $18,18 \%$ dengan rerata 62,73. Pada akhir tahap Terapkan, guru meluruskan konsep yang salah dan memberikan contoh cara-cara pintar dalam menyerap informasi.

Guru pada dua pertemuan pertama telah melakukan langkah-langkah pembelajaran dengan tepat, karena sering atau selalu menunjukkan aspek-aspek yang diamati. Sehingga hal-hal yang perlu diperbaiki dalam pembelajaran berdasar hasil pengamatan observer adalah : 1. Guru : kurang tegas dalam pengaturan waktu ketika siswa mengerjakan soal, masih mendominasi kelas sehingga siswa pasif, perhatian terhadap masing-masing siswa belum maksimal, 2. Siswa : banyak siswa tidak dapat menyelesaikan soal tepat waktu, masih tampak tegang, takut jika mendapat pertanyaan, keberanian siswa dalam mengemukakan pendapat masih kurang, banyak siswa diam, tidak semua anggota dalam kelompok aktif

Dari data di atas sebagai hasil pengamatan pada pertemuan pertama dan kedua, maka hal-hal yang perlu untuk dipertahankan adalah : 1. Guru : penjelasan tentang materi cukup bagus dan jelas., memberi kesempatan siswa untuk menjelaskan alasan solusi pemecahan masalah yang diserap, 2. Siswa : Beberapa siswa ada yang sudah berani mengemukakan pendapat.

Berdasar hasil analisis dari pengamatan pada siklus pertama penelitian didapatkan hasil sebagai berikut. 1). Keaktifan siswa sudah mulai ada kemajuan sudah ada beberapa siswa yang berani mengemukakan pendapat. Ini merupakan kemajuan walaupun belum maksimal. Kemajuan tersebut masih jauh dari target yang ditentukan yaitu $75 \%$ siswa aktivitasnya tergolong dalam kategori baik. Dari tabel 1 tercatat tidak ada siswa yang termasuk dalam kategori amat baik dan kastegori baik, 7 siswa cukup dan 8 siswa kategori kurang dari 15 siswa di Kelas IV Jika dihitung prosentasenya berarti $41,73 \%$ siswa termasuk dalam kategori baik termasuk amat baik dan 50\% kategori cukup yang 8,33\% kategori kurang padahal target yang ditetapkan adalah $75 \%$.Dapat dikatakan bahwa yang dapat dicapai sekarang baru pada tingkatan kategori cukup, sehingga masih perlu 
adanya upaya- upaya peningkatan pada siklus berikutnya. 2). Kemampuan siswa yang ditunjukan dengan nilai rerata sudah mengalami kemajuan dari 55 menjadi 62,08 namun kemajuan ini masih relatif kecil, mengingat indikator keberhasilan yang ditetapkan adalah $75 \%$ siswa mencapai ketuntasan dalam mendeskripsikan pengertian organisasi. Tetapi sebenarnya dengan kenaikan 7,08 itu sudah lumayan walaupun belum merubah kedudukan prosentase pencapaian ketuntasan belajar, berarti dari 15 siswa peserta penelitian yang mencapai ketuntasan adalah 2 siswa. 3) Aktifitas guru dan pengelolaan terhadap pembelajaran sudah tepat, karena sering atau selalu memunculkan aspek-aspek yang diamati dan sesuai dengan langkah pembelajaran SMaRT Learning Pada pertemuan kedua sebenarnya sudah merupakan refleksi pada pertemuan pertama sehingga terjadi perubahanperubahan sesuai masukan dari observer. Berdasar pendapat observer maka untuk siklus kedua, hal-hal yang perlu dilakukan adalah sebagai berikut : 1. Pada siklus kedua, materi telah dikembangkan. dengan harapan tingkat berpikir siswa lebih kreatif. 2. Pengelompokan siswa tidak didasarkan pada nomor urut absensi, tetapi didasarkan sesuai dengan teman sebangkunya. 3. Memberi perhatian penuh kepada siswa yang belum mampu mendeskripsikan pengertian organisasi 4.Mengurangi dominasi guru dengan banyak meminta siswa aktif menyelesaikan tugas secara kelompok maupun mandiri

Sebagai perbaikan siklus 1, guru memberikan tes gaya belajar dan implementasinya dalam pembelajaran. Tetapi ini dimaksudkan untuk memberikan alternative dalam memperbaiki cara belajar siswa. a. Perencanaan, pada tahap perencanaan ini, hal-hal yang dilakukan guru adalah : 1) Menyusun perbaikan Rencana Pelaksanaan Pembelajaran (RPP), 2) Menyusun perbaikan rencana tindakan, 3) Menyiapkan media yang akan digunakan, 4) Menyusun perbaikan instrument dan pedoman observasi, tes dan catatan lapangan, 5) Menyusun perbaikan rencana penilaian. b. Tindakan, Pertemuan 1, .Kegiatan yang dilakukan berupa rencana perbaikan kegiatan yang dilakukan pada siklus I. Materi ajar pada siklus II dipelajari. Diharapkan Metode SMaRT Learning lebih menarik perhatian siswa. Pada tahap Serap guru mengajak siswa mengamati gambar Newton, orang yang berjasa besar di dunia pengetahuan khususnya Pendidikan Kewarganegaraan sambil sedikit mengungkap sejarah penemuannya.

Kegiatan selanjutnya guru memberi penjelasan singkat tentang materi ajar. Pada tahap Maknai, guru memutar : LCD tentang materi ajar. Siswa menyerap informasi sesuai dengan gaya belajar masing-masing. informasi yang diperolehnya. Guru melakukan pengamatan tentang perilaku siswa selama mengikuti pembelajaran dan iklim pembelajaran Pendidikan Kewarganegaraan. Pada tahap Rayakan guru menugasi siswa untuk memaknai informasi yang diperoleh. Pertemuan ini diakhiri menuliskan refleksi. Pertemuan 2, Guru mengadakan dialog interaktif yang berkisar pada materi ajar pertemuan pertama. Selanjutnya guru meminta siswa untuk memaknai materi ajar dalam berbagai bentuk. Seperti pada siklus pertama guru menyuruh siswa untuk melakukan refleksi tertulis. Untuk menentukan tindak lanjut guru meminta siswa untuk melakukan presentasi seperti halnya pada siklus I. Kegiatan ini diakhiri dengan ulangan tahap 2 . 
Jika dilihat dari tingkat ketuntasan belajar siswa diketahui bahwa hasil belajar siklus I terendah adalah 65 sedangkan tertinggi 80 Skor rata-rata siswa adalah 66,09. dengan tingkat ketuntasan 54,55\%. Berarti terdapat 6 siswa yang mampu mencapai nilai 75 atau lebih. Jadi kemampuan siswa dalam menyebutkan contoh organisasi di lingkungan sekolah dan masyatakat tergolong cukup dan belum memenuhi indikator keberhasilan yang ditetapkan yaitu $75 \%$. Oleh karena itu perlu ditingkatkan lagi pada pertemuan berikutnya.

Hasil pengamatan terhadap guru penerapan model SMaRT Learning menunjukkan hasil cukup memuaskan karena guru telah mengikuti langkahlangkah SMaRT Learning dengan benar.

Selama tahap Serap, Maknai dan Rayakan diperoleh data sebagai berikut : menit 1 sampai menit 20, siswa konsentrasi memnyerap, memaknai dan menyimak hasil pemaknaannya. Mulai menit ke 15, ada 3 siswa yang ke luar ruangan dan 12 siswa tetap berada di ruangan dengan tingkah laku beragam. Bentuk refleksi tertutis siswa sebagai berikut : 4 bentuk table, 2 bentuk ringkasan deskriptif yang ditandai, 6 bentuk ringkasan deskriptif tanpa ditandai. Hasil penilaian refleksi terlampir.

Pada akhir tahap Terapkan, guru menguatkan konsep materi yang telah dipelajari Pada ulangan tahap 2 siswa yang memperoleh nilai 75 ke atas 54,55\% dengan rerata 66,09. Hasil observasi menunjukkan perubahan kearah keberagaman, demikian pula bentuk refleksinya. Berdasarkan data tersebut maka pada siklus 3 direncanakan siswa melakukan tahap Serap, Maknai dan Rayakan secara mandiri di rumah. Kelemahan pada siklus ini siswa belum mampu menandai konsep-konsep penting dengan menggarisbawahi atau menggunakan spidol.

Berdasar hasil analisis dari pengamatan pada siklus pertama penelitian didapatkan hasil sebagai berikut : 1). Keaktifan siswa sudah mulai ada kemajuan sudah ada beberapa siswa yang berani mengemukakan pendapat dan dalam kegiatan kelompok sudah mulai kompak. Ini merupakan kemajuan walaupun belum maksimal. Kemajuan tersebut masih jauh dari target yang ditentukan yaitu $75 \%$ siswa aktivitasnya tergolong dalam kategori baik. Dari tabel 3 tercatat ada 3 siswa yang termasuk dalam kategori baik atau amat baik dari 15 siswa di Kelas IV Jika dihitung prosentasenya berarti $24,99 \%$ siswa termasuk dalam kategori baik padahal target yang ditetapkan adalah $75 \%$.Dapat dikatakan bahwa yang dapat dicapai sekarang baru pada tingkatan kategori cukup, sehingga masih perlu adanya upaya- upaya peningkatan pada siklus berikutnya, 2) Kemampuan siswa dalam memberi contoh organisasi di lingkungan sekolah dan masyarakat sudah mengalami kemajuan dari $18,18 \%$ siswa menjadi $54,55 \%$. Peningkatan ini sudah mendekati target indikator keberhasilan yang ditetapkan adalah $75 \%$ siswa mencapai ketuntasan dalam Dengan kenaikan 36,37\% itu sudah lumayan, berarti dari 15 siswa peserta penelitian yang mencapai ketuntasan adalah 8 siswa. 3) Aktifitas guru dan pengelolaan terhadap pembelajaran sudah tepat, karena sering atau selalu memunculkan aspek-aspek yang diamati dan sesuai dengan langkah pembelajaran dengan SMaRT Learning.

Berdasar pendapat observer tersebut, maka untuk siklus kedua, hal-hal yang perlu dilakukan adalah sebagai berikut : 1. Pada siklus ketiga, materi 
dikembangkan pada kompetensi dasar berikutmya. 2. Pengelompokan siswa tidak didasarkan pada nomor urut absensi, tetapi didasarkan sesuai dengan teman sebangkunya. 3. Memberi perhatian penuh kepada siswa yang belum mampu memberikan contoh organisasi di lingkungan sekolah dan masyarakat. 4. Memberi kesempatan kepada siswa yang mampu untuk membantu memberikan penjelasan kepada temannya yang belum mengerti. 5. Sering mengingatkan kepada siswa agar tidak ceroboh dalam mengerjakan soal dan menyuruh siswa mengembalikan jawaban pada soal semula.

Atas dasar hasil refleksi pada siklus II, perlu dilakukan perbaikan rencana kegiatan yang telah dilakukan. Langkah-langkah kegiatan pada siklus III berupa perbaikan pada siklus sebelumnya. Adapun alur kegiatan pada siklus III ini, sebagai berikut : a. Perencanaan : Kegiatan yang dilaksanakan pada tahap perencanaan ini, meliputi : Menyusun perbaikan Rencana Pelaksanaan Pembelajaran (RPP), Menyusun perbaikan rancangan tindakan, Menyusun perbaikan instrumen penilaian, Menyusun perbaikan penilaian, Guru menyiapkan media yang diperlukan. b.Tindakan, Kegiatan yang dilakukan diantaranya perbaikan kegiatan yang telah dilakukan pada saiklus II. Pada siklus III tahap Serap, Maknai dan Rayakan dilaksanakan siswa secara berkelompok di rumah Adapun tahap Terapkan dilaksanakan di sekolah. Seperti halnya siklus II Guru mengadakan dialog tentang materi ajar, kemudian dilanjutkan kegiatan memaknai informasi yang diserap dalam berbagai bentuk dengan caranya sendiri dan siswa bebas kreatifitas, dan dilanjutkan presentasi. Pada tahap akhir tindakan ini siswa juga diminta membuat refleksi tertulis dan mengerjakan ulangan tahap 3, sebagai tolok ukur untuk menentukan tindakan pada siklus berikutnya. Dengan Rentang skor pada siklus III dari 20-100, ternyata skor terendah 65 dengan skor tertinggi 90 dengan perolehan rata-rata adalah 79,09.

Jika dilihat dari tingkat ketuntasan belajar siswa diketahui bahwa hasil belajar terendah adalah 65 sedangkan tertinggi 90. Skor rata-rata siswa adalah 79,09 dan tingkat ketuntasan 90,91\%. Berarti terdapat 13 siswa yang mampu mencapai nilai 75 atau lebih. Jadi kemampuan siswa dalam memberi contoh organisasi di lingkungan sekolah dan lingkungan sudah mengalami kemajuan pesat dan telah melebihi indikator keberhasilan yang ditetapkan yaitu $75 \%$. Untuk meyakinkan peningkatan yang terjadi maka siklus dilanjutkan.

Sebagai perbaikan siklus II siswa diberi penjelasan tentang pentingnya menggarisbawahi, menandai atau memberi warna. Pada awal pertemuan siswa mengumpulkan hasil refleksinya beberapa siswa mengumpulkan terlambat karena terpengaruh oleh hasil refleksi temannya dan melakukan perbaikan. Bentuk refleksi tertulis siswa sangat beragam : puisi, skema, ringkasan deskriptif, tabel, akronim dan gambar. Hampir semua hasil refleksi ditandai/diwarnai. Hasil penilaian refleksi terlampir.

Nilai observasi presentasi 88 , dengan 7 orang penanya. Pada akhir tahap Terapkan, guru menguatkan beberapa kinsep penting. Pada ulangan tahap 2 siswa yang memperoleh nilai 75 keatas $=75 \%$ dengan rerata kelas 66,09. Data menunjukkan bahwa nilai rata-rata hasil refleksi sudah meningkat. Selain karena hasil perlakuan, hal ini juga disebabkan karena siswa mempunyai cukup waktu untuk melakukan tahap Serap, Maknai . Rayakandan Terapkan. Tetapi terjadi

11 BRILIANT: Jurnal Riset dan Konseptual Volume 1 Nomor 1, November 2016 
penurunan pada aspek 1,4,dan 6 , serta jumlah yang mencapai nilai 75 ke atas. Hal; ini disebabkan karena guru tidak memberitahu hasil belajar yang harus dicapai . Akibatnya konsep yang direfleksikan tidak lengkap dan hasil refleksi kurang sistematis sehingga siswa menemui hambatan untuk memahami dan mengingat konsep kembali. Kelemahan lain adalah masih banyak siswa yang menggarisbawai / mewarnai hampir seluruh hasil refleksinya.

Hasil pengamatan terhadap guru ketika pembelajaran dengan SMaRT Learning adalah guru pada dua pertemuan di siklus III telah melakukan langkahlangkah pembelajaran dengan tepat, karena selalu menunjukkan aspek-aspek yang diamati.

Dari data di atas sebagai hasil pengamatan pada pertemuan kelima dan keenam maka hal-hal yang perlu untuk dipertahankan menurut pendapat observer adalah 1. Guru : Dalam membimbing siswa yang belum jelas tidak langsung dijawab tetapi memancing siswa untuk berpikir sendiri tentang solusinya, Memberi kesempatan siswa untuk mengkritisi penyelesaian soal sehingga suasana kelas menjadi lebih hidup, 2. Siswa : Sudah mulai ada kekompakan dalam kelompok

Berdasar hasil analisis dari pengamatan pada siklus ketiga penelitian didapatkan hasil sebagai berikut. 1). Keaktifan siswa sudah mengalami kemajuan pesat dengan indikator bahwa siswa sudah kompak dalam kelompoknya disamping itu, siswa sudah berani mengemukakan pendapat. Dari tabel 5 tercatat ada 1 siswa yang termasuk dalam kategori baik atau amat baik dari 15 siswa di Kelas IV. Jika dihitung prosentasenya berarti 91,67\% siswa termasuk dalam kategori baik sehingga dengan target $75 \%$ dapat dikatakan bahwa pada siklus III ini telah berhasil. 2). Kemampuan siswa dalam dalam belajar mengalami kemajuan dari 54,55\% siswa menjadi $90,91 \%$. Peningkatan ini sudah jauh melebihi indikator keberhasilan yang ditetapkan adalah $75 \%$ siswa mencapai ketuntasan Dengan kenaikan 36,36\% itu sangat bagus, berarti dari 15 siswa peserta penelitian yang mencapai ketuntasan adalah 13 siswa. 3. Aktifitas guru dan pengelolaan terhadap pembelajaran sudah tepat, karena selalu memunculkan aspek-aspek yang diamati dan sesuai dengan langkah pembelajaran dengan SMaRT Learning.

Mengacu hasil penelitian pada siklus III maka pada siklus IV ini, guru merencanakan tindakan yang akan diterapkan selama proses penelitian. Adapun langkah-langkah kegiatan yang ditempuh, sebagai berikut : a. Perencanaan, Kegiatan yang dilakukan pada tahap perencanaan ini, meliputi hal-hal sebagai berikut : Penyusunan perbaikan rencana pelaksanaan pembelajaran (RPP) dalam rangka upaya perbaikan siklus III : 1) Menyusun perbaikan instrument dan pedoman tes, observasi , catatan lapangan, 2) Menyusun perbaikan rancangan evaluasai, 3) Menyiapkan media pembelajaran yang diperlukan.

Kegiatan yang dilaksanakan pada tahap tindakan di siklus IV ini pada dasarnya merupakan perbaikan kegiatan yang dilakukan pada siklus sebelumnya. Seperti halnya siklus III, maka tahap Serap, Maknai dan Rayakan dilaksanakan di rumah. Tahap Terapkan dilaksanakan di sekolah dengan langkah-langkah seperti pada siklus III yakni Guru mengadakan dialog atau tanya jawab berkisar materi ajar tentang menampilkan peran serta dalam memilih organisasi di sekolah yang

12 BRILIANT: Jurnal Riset dan Konseptual

Volume 1 Nomor 1, November 2016 
telah dipelajari di rumah Guru meminta siswa untuk memaknai materi ajar yang diserap, dilanjutkan presentasi. Kegiatan diakhiri dengan adanya refleksi tertulis, siswa ditugasi mengerjakan tes.

Observasi dimaksudkan untuk melakukan pengukuran atau pengumpulan data sesuai masalah dan fokus penelitiannya. Kecermatan dan ketelitian sangat duanjurkan demi keakuratan dan kesempurnaan hasil yang diperoleh dari Penelitian Tindakan Kelas ini. Dengan demikian dimungkinkan peneliti memperoleh temuan tindakan. Diharapkan tercipta iklim pembelajaran yang harmonis.

Skor pada siklus IV dari 20-100, ternyata skor terendah 75 dengan skor tertinggi 95 dengan perolehan rata-rata adalah 85,45. Adapun ketuntasan belajar siswa pada siklus IV ini menunjukkan bahwa kemampuan memberi contoh organisasi di lingkungan sekolah dan masyarakat tentang, terendah adalah 75 dan tertinggi mencapai 95.

Pembenahan yang dilakukan pada siklus ini ialah guru menyampaikan hasil belajar yang harus dicapai sebelum menugasi siswa melakukan tahap Serap, Maknai, Rayakan dan Terapkan serta cara menggaris bawahi atau mewarnai yang benar. Hasil refleksi tertulis sangat beragam berupa puisi, skema, ringkasan deskriptif, table membuat akronim dan gambar. Hasil penilaian refleksi tertulis terlampir. Pada ulangan siswa yang memperoleh 75 ke atas $100 \%$ dengan rerata kelas 85,45. Setelah siklus IV selesai siswa diminta untuk menuliskan pendapatnya tentang pembelajaran yang telah dilakukan dengan mengisi angket tertutup, yang hasilnya seperti pada tabel 1 berikut.

Dari hasil angket yang dituliskan siswa dapat ditarik simpulan bahwa siswa memberi respon positif terhadap pembelajaran, karena banyaknya siswa yang memilih setuju lebih banyak daripada siswa yang tidak setuju untuk tiap butir angket.

Atas dasar hasil observasi, dilakukan refleksi, yang mencakup hal-hal sebagai berikut : 1) Pengungkapan hasil observasi oleh peneliti. 2) Pengungkapan tindakan-tindakan yang telah dilakukan siswa selama proses belajar mengajar. 3) Pengungkapan tindakan-tindakan yang telah dilakukan guru selama proses pembelajaran.

Berdasarkan hasil analisis data hasil penelitian, maka dapat ditarik keputusan bahwa Hasil belajar Pendidikan Kewarganegaraan ( Memahami Sistem pemerintahan kabupaten, kota, dan propinsi) siswa Kelas IV SDN Punung II Semester II Tahun Pelajaran 2015/2016 dapat ditingkatkan melalui SMaRT Learning.

Kenyataan membuktikan bahwa penggunaan SMaRT Learning dalam pembelajaran Pendidikan Kewarganegaraan dapat meningkatkan hasil belajar siswa. Karena SMaRT Learning mampu melibatkan siswa secara aktif dan mengarah pada terwujudnya belajar mandiri. Hal ini telah terbukti bahwa dalam setiap siklus- siklusnya mampu meraih nilai rerata kelas di atas standar ketuntasan belajar Pendidikan Kewarganegaraan yang telah ditetapkan.

Banyak faktor yang mempengaruhi peningkatan Hasil belajar Pendidikan Kewarganegaraan salah satu diantaranya adalah penggunaan metode pembelajaran. Berdasarkan hasil analisis deskriptif secara umum dapat dilihat 
dari hasil penelitian tentang Aktifitas belajar Pendidikan Kewarganegaraan pada siklus I berada kategori rendah,Siklus II kategori Cukup, Siklus III sudah merubah posisi pada kategori baik, dan pada siklus IV aktifitas belajar siswa poada kategori amat baik

Sedangkan hasil penelitian hasil belajar Pendidikan Kewarganegaraan dengan SMaRT Learning menunjukkan peningkatan mean skor dalam setiap siklusnya yaitu Siklus I mencapai mean skor 62,73, siklus II meningkat menjadi 66,09, siklus III naik menjadi 79,09 dan siklus IV sebagai siklus terakhir mencapai 85,45. dapat diartikan bahwa SMaRT Learning mampu meningkatkan hasil belajar Pendidikan Kewarganegaraan.

Adapun hasil penelitian pencapaian ketuntasan belajar juga mengalami kenaikan dalam setiap siklusnya yakni siklus I mencapai $18,18 \%$; siklus II naik menjadi 54,55\%, siklus III meningkat menjadi $90,91 \%$ dan siklus IV mencapai $100 \%$ Hal ini menunjukkan bahwa SMaRT Learning memang cocok diterapkan dalam meningkatkan hasil belajar Pendidikan Kewarganegaraan.

Tingginya peningkatan hasil belajar siswa dalam belajar Pendidikan Kewarganegaraan disebabkan siswa telah memiliki respon yang positif terhadap pelajaran Pendidikan Kewarganegaraan yang ditunjang demngan adanya rincian kegiatan pembelajaran yang menyenangkan disertai penggunaan SMaRT Learning.

Dari uraian tersebut dapat disimpulkan bahwa SMaRT Learning dapat dimanfaatkan untuk meningkatkan hasil belajar Pendidikan Kewarganegaraan pada khususnya dan hasil belajar siswa pada umumnya.

\section{KESIMPULAN}

Penerapan SMaRT Learning dapat meningkatkan kemandirian belajar siswa. Kemandirian tersebut berdampak pada peningkatan pemahaman konsep siswa atau dapat dikatakan bahwa hasil belajar Pendidikan Kewarganegaraan tentang system pemerintahan kabupaten,kota, dan propinsi siswa Kelas IV SDN Punung II Semester II Tahun Pelajaran 2015/2016 dapat ditingkatkan melalui SMaRT Learning.

\section{SARAN}

Saran untuk Guru, (1) Guru sebagai pengelola proses pembelajaran, hendaknya guru berani mengujicobakan model-model pembelajaran baru untuk meningkatkan hasil belajar siswa, (2) SMaRT Learning dapat digunakan sebagai alternative untuk meningkatkan kemandirian dan hasil belajar siswa dengan tetap memperhatikan tingkat perkembangan siswa.

\section{DAFTAR PUSTAKA}

Amstrong, Thomas. 2002. Setiap Anak Cerdas: Panduan Membantu Anak Belajar dengan Memanfaatkan Multiple Inteligencenya. Jakarta: Gramedia Pustaka Utama

14 BRILIANT: Jurnal Riset dan Konseptual

Volume 1 Nomor 1, November 2016 
BNSP. 2006. Standar Isi. Badan standar Nasional Pendidikan. Jakarta

Depdiknas. 1989..Kamus Besar Bahasa Indonesia. Jakarta: Balai Pustaka.

Hamalik, Oemar. 2009. Proses Belajar Mengajar.Jakarta. PT. Bumi Aksara.

Madden, Thomas L. 2002. F.I.R.E.U.P Your Learning: Tingkatkan Rangking Anda. Jakarta: Gramedia Pustaka Utama.

Nur, Muhammad. 2000. Strategi-Strategi Belajar. Surabaya: Unesa University Press

Tim Peneliti Program Pasca Sarjana UNY. 2004. Pedoman Pembuatan Laporan Hasil Belajar.Departemen Pendidikan Nasional Dirjen Dikdasmen Direktorat Pendidikan Lanjutan Pertama.

Uno, Hamzah. 2009. Model Pembelajaran Menciptakan Proses Belajar Mengajar yang Kreatif dan Efektif. Jakarta: PT.Bumi Aksara. 